\title{
Anti-human Immunodeficiency Virus-1 Protease Activity of New Lanostane-Type Triterpenoids from Ganoderma sinense
}

\author{
Naoto SATo, Qun Zhang, Chao-Mei Ma, and Masao Hattori* \\ Institute of Natural Medicine, University of Toyama; 2630 Sugitani, Toyama 930-0194, Japan.
}

Received April 17, 2009; accepted July 27, 2009; published online July 29, 2009

Five new highly oxygenated lanostane-type triterpenoids [ganoderic acid GS-1 (1), ganoderic acid GS-2 (2), ganoderic acid GS-3 (3), 20(21)-dehydrolucidenic acid N (4) and 20-hydroxylucidenic acid A (5)] were isolated from the fruiting body of Ganoderma sinense, together with known compounds including 6 triterpenoids and 3 sterols. The structures of the new triterpenoids determined by spectroscopic means including 2D NMR were $7 \beta$ hydroxy-3,11,15-trioxo-lanosta-8,24(E)-dien-26-oic acid $(1), 7 \beta, 15 \alpha$-dihydroxy-3,11-dioxo-lanosta-8,24(E)-dien26-oic acid (2), $12 \beta$-acetoxy-3 $\beta, 7 \beta$-dihydroxy-11,15-dioxo-lanosta-8,24(E)-dien-26-oic acid (3), $3 \beta, 7 \beta$-dihydroxy11,15-dioxo-25,26,27-trinorlanosta-8,20-dien-24-oic acid (4), and 7 $\beta, 20 \xi$-dihydroxy-3,11,15-trioxo-25,26,27-trinorlanost-8-en-24-oic acid (5), respectively. Among these, ganoderic acid GS-2, 20-hydroxylucidenic acid N, 20(21)-dehydrolucidenic acid $\mathrm{N}$ and ganoderiol $\mathrm{F}$ inhibited human immunodeficiency virus-1 protease with $\mathrm{IC}_{50}$ values of $20-40 \mu \mathrm{M}$.

Key words ganoderic acid; human immunodeficiency virus-1 protease inhibition; AIDS; herbal drug; Ganoderma sinense

Ganoderma species have long been used in China, Japan, Korea and other Asian countries as a source of valuable herbal drugs. Ganoderma lucidum KARST. (Polyporaceae) is particularly well known and its constituents have been studied for several decades. Over 140 highly oxygenated triterpenoids have been isolated and characterized from $G$. lucidum $^{1-3)}$ over the past 30 years and some of them have biological activities of interest. ${ }^{1,4-10)}$ In contrast, little is known about $G$. sinense, which is similar to G. lucidum. ${ }^{11-13)} G$. sinense is registered in the Chinese Pharmacopoeia together with G. lucidum, and it is available on the Chinese crude drug market. A preliminary HPLC analysis of bitter principles during our ongoing evaluation of Ganoderma species revealed that the fruiting bodies of $G$. sinense contain some triterpenoids that differ from those of $G$. lucidum. ${ }^{1,14)} \mathrm{We}$ therefore searched for pharmacologically active constituents generated by this mushroom. We already reported that some triterpenes appreciably inhibit human immunodeficiency virus (HIV)-protease, ${ }^{1,9,10,15)}$ possibly through dimerization inhibition. ${ }^{15)}$ Here, we elucidated the structures of five new lanostane-type triterpenoids $(\mathbf{1}-\mathbf{5})$, and compared the antiHIV-1 protease activities of novel lanostane-type triterpenoids isolated from $G$. sinense with those from G. lucidum.

\section{Results and Discussion}

Isolation and Structure Determination Repeated column chromatography of a chloroform extract of the fruiting body of $G$. sinense resulted in the isolation of eleven triterpenoids and three sterols. A comparison of their spectroscopic data with reported ones revealed the known compounds, ganoderic acid $\beta$ (6), ${ }^{10)}$ 20(21)-dehydrolucidenic acid A (7), ${ }^{16)}$ 20-hydroxylucidenic acid N (8), ${ }^{16)}$ lucidenic acid D2 (9), ${ }^{17)}$ ganodermanontriol $(\mathbf{1 0}),{ }^{18)}$ ganoderiol F (11),${ }^{19)}$ cerevisterol (12), 5,6-dihydroergosterol (13) and ergosterol peroxide (14). These compounds have been isolated from G. lucidum.

The structures of the new compounds were determined as follows. Ganoderic GS-1 (1) was obtained as a white amorphous powder; $[\alpha]_{\mathrm{D}}+130.4\left(\mathrm{CHCl}_{3}\right)$. The molecular formula of 1 was $\mathrm{C}_{30} \mathrm{H}_{42} \mathrm{O}_{6}$, estimated from the high-resolution electron impact mass spectrometric (HR-EI-MS) spectrum $(\mathrm{m} / \mathrm{z}$ 498.2932 [M] $]^{+}$, Calcd for $\mathrm{C}_{30} \mathrm{H}_{42} \mathrm{O}_{6}$ 498.2981). The UV absorption at $253 \mathrm{~nm}(\log \varepsilon 3.9)$ and the IR band at $1660 \mathrm{~cm}^{-1}$ suggested an $\alpha, \beta$-unsaturated carbonyl group. The ${ }^{1} \mathrm{H}-\mathrm{NMR}$ spectrum (Table 1) showed signals for six tertiary methyls, a secondary methyl $\left(\delta_{\mathrm{H}} 1.02 \mathrm{~d}, J=6.0 \mathrm{~Hz}\right)$, an oxymethine $\left(\delta_{\mathrm{H}}\right.$ $4.86 \mathrm{dd}, J=9.0,7.5 \mathrm{~Hz})$ and an olefinic methine $\left(\delta_{\mathrm{H}} 6.85 \mathrm{t}\right.$, $J=8.0 \mathrm{~Hz}$ ). The ${ }^{13} \mathrm{C}-\mathrm{NMR}$ spectrum (Table 2), analyzed with the aid of distortionless enhancement by polarization transfer

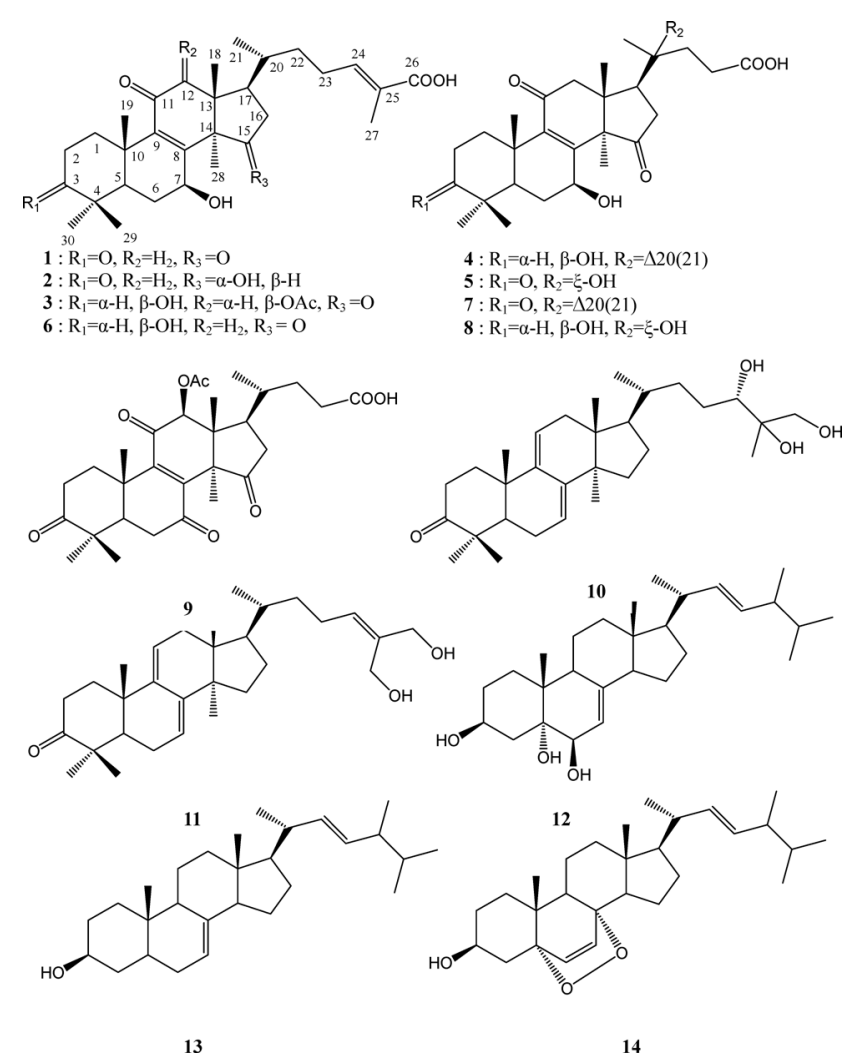

Fig. 1. Structures of Compounds 1-14 Isolated from $G$. sinense 
Table 1. ${ }^{1} \mathrm{H}-\mathrm{NMR}$ Data $(500 \mathrm{MHz})$ of $\mathbf{1}-\mathbf{5}\left(\right.$ in $\left.\mathrm{CDCl}_{3}\right)$

\begin{tabular}{|c|c|c|c|c|c|}
\hline Position & 1 & 2 & 3 & 4 & 5 \\
\hline \multirow[t]{2}{*}{1} & $1.47 \mathrm{~m}$ & $1.47 \mathrm{~m}$ & $0.97 \mathrm{~m}$ & $0.96 \mathrm{~d}$-like, $J=10.0 \mathrm{~Hz}$ & 1.48 d-like, $J=10.0 \mathrm{~Hz}$ \\
\hline & $2.95 \mathrm{~m}$ & $2.95 \mathrm{ddd}, J=13.0,7.0,5.5 \mathrm{~Hz}$ & $2.63 \mathrm{~m}$ & $2.79 \mathrm{~m}$ & $2.96 \mathrm{~m}$ \\
\hline \multirow[t]{2}{*}{2} & $2.44 \mathrm{~m}$ & $2.49 \mathrm{~m}$ & $1.63 \mathrm{~m}$ & $1.63 \mathrm{~m}$ & $2.45 \mathrm{~m}$ \\
\hline & $2.54 \mathrm{~m}$ & $2.54 \mathrm{~m}$ & & & $2.52 \mathrm{~m}$ \\
\hline 3 & - & - & $3.21 \mathrm{dd}, J=10.5,5.0 \mathrm{~Hz}$ & $3.21 \mathrm{dd}, J=10.5,5.0 \mathrm{~Hz}$ & - \\
\hline 5 & $1.57 \mathrm{~d}, J=13.0 \mathrm{~Hz}$ & $1.77 \mathrm{~m}$ & $0.86 \mathrm{~m}$ & 0.86 brd & $1.55 \mathrm{~d}, J=13.0 \mathrm{~Hz}$ \\
\hline \multirow[t]{2}{*}{6} & $1.68 \mathrm{~m}$ & $1.69 \mathrm{~m}$ & $1.64 \mathrm{~m}$ & $1.61 \mathrm{~m}$ & 1.61 like s \\
\hline & $2.11 \mathrm{~m}$ & $2.04 \mathrm{~m}$ & $2.24 \mathrm{~m}$ & $2.68 \mathrm{~m}$ & $2.09 \mathrm{~m}$ \\
\hline 7 & $4.86 \mathrm{dd}, J=9.0,7.5 \mathrm{~Hz}$ & $4.64 \mathrm{dd}, J=10.0,7.5 \mathrm{~Hz}$ & $4.81 \mathrm{dd}, J=9.0,7.5 \mathrm{~Hz}$ & $4.82 \mathrm{dd}, J=9.5,8.0 \mathrm{~Hz}$ & $4.83 \mathrm{dd}, J=9.5,8.0 \mathrm{~Hz}$ \\
\hline \multirow[t]{2}{*}{12} & $2.77 \mathrm{~s}(2 \mathrm{H})$ & $2.54 \mathrm{~d}, J=16.0 \mathrm{~Hz}$ & $5.63 \mathrm{~s}$ & $2.58 \mathrm{~d}, J=9.0 \mathrm{~Hz}$ & $2.81 \mathrm{~s}(2 \mathrm{H})$ \\
\hline & & $2.76 \mathrm{~d}, J=16.0 \mathrm{~Hz}$ & & $2.83 \mathrm{~d}, J=9.0 \mathrm{~Hz}$ & \\
\hline 15 & - & $4.79 \mathrm{dd}, J=9.0,6.5 \mathrm{~Hz}$ & - & & \\
\hline \multirow[t]{2}{*}{16} & $2.08 \mathrm{~m}$ & $1.81 \mathrm{~m}$ & $2.26 \mathrm{~m}$ & $2.61 \mathrm{~m}$ & $2.49 \mathrm{~m}$ \\
\hline & $2.76 \mathrm{~m}$ & $1.89 \mathrm{~m}$ & $2.68 \mathrm{~m}$ & & $2.61 \mathrm{~m}$ \\
\hline 17 & $2.02 \mathrm{~m}$ & $2.48 \mathrm{~m}$ & $2.46 \mathrm{~m}$ & $2.99 \mathrm{dd}, J=9.0,9.0 \mathrm{~Hz}$ & $2.50 \mathrm{~m}$ \\
\hline 18 & $1.01 \mathrm{~s}$ & $0.97 \mathrm{~s}$ & $0.97 \mathrm{~s}$ & $0.88 \mathrm{~s}$ & $1.18 \mathrm{~s}$ \\
\hline 19 & $1.26 \mathrm{~s}$ & $1.28 \mathrm{~s}$ & $1.27 \mathrm{~s}$ & $1.13 \mathrm{~s}$ & $1.26 \mathrm{~s}$ \\
\hline 20 & $1.56 \mathrm{~m}$ & $1.43 \mathrm{~m}$ & $1.69 \mathrm{~m}$ & & \\
\hline 21 & $1.02 \mathrm{~d}, J=6.0 \mathrm{~Hz}$ & $0.92 \mathrm{~d}, J=6.5 \mathrm{~Hz}$ & $1.00 \mathrm{~d}, J=6.0 \mathrm{~Hz}$ & $4.88 \mathrm{~s}, 5.03 \mathrm{~s}$ & \\
\hline \multirow[t]{2}{*}{22} & $1.51 \mathrm{~m}$ & $1.53 \mathrm{~m}$ & $1.47 \mathrm{~m}$ & $2.28 \mathrm{~m}$ & $2.02 \mathrm{~m}$ \\
\hline & & & & $2.42 \mathrm{~m}$ & $2.08 \mathrm{~m}$ \\
\hline 23 & $2.17 \mathrm{~m}$ & $2.14 \mathrm{~m}$ & $2.19 \mathrm{~m}$ & $2.56 \mathrm{~m}$ & $\begin{array}{c}2.49 \mathrm{t} J=7.5 \mathrm{~Hz} \\
2.61 \mathrm{~m}\end{array}$ \\
\hline 24 & $6.85 \mathrm{t}, J=8.0 \mathrm{~Hz}$ & $6.87 \mathrm{t}, J=8.0 \mathrm{~Hz}$ & $6.85 \mathrm{t}, J=7.0 \mathrm{~Hz}$ & & \\
\hline 27 & $1.86 \mathrm{~s}$ & $1.84 \mathrm{~s}$ & $1.85 \mathrm{~s}$ & & \\
\hline 28 & $1.35 \mathrm{~s}$ & $1.26 \mathrm{~s}$ & $1.49 \mathrm{~s}$ & $1.38 \mathrm{~s}$ & $1.37 \mathrm{~s}$ \\
\hline 29 & $1.11 \mathrm{~s}$ & $1.11 \mathrm{~s}$ & $0.86 \mathrm{~s}$ & $0.83 \mathrm{~s}$ & $1.10 \mathrm{~s}$ \\
\hline 30 & $1.13 \mathrm{~s}$ & $1.12 \mathrm{~s}$ & $1.03 \mathrm{~s}$ & $0.99 \mathrm{~s}$ & $1.10 \mathrm{~s}$ \\
\hline $\mathrm{MeCO}$ & - & - & $2.22 \mathrm{~s}$ & $0.99 \mathrm{~s}$ & $1.13 \mathrm{~s}$ \\
\hline
\end{tabular}

Table 2. ${ }^{13} \mathrm{C}-\mathrm{NMR}$ Data $(500 \mathrm{MHz})$ of $\mathbf{1}-\mathbf{5}\left(\right.$ in $\left.\mathrm{CDCl}_{3}\right)$

\begin{tabular}{|c|c|c|c|c|c|}
\hline Position & 1 & 2 & 3 & 4 & 5 \\
\hline 1 & 35.6 & 35.7 & 34.4 & 34.7 & 35.8 \\
\hline 2 & 34.4 & 34.5 & 27.4 & 27.5 & 34.1 \\
\hline 3 & 216.8 & 218.0 & 78.2 & 78.3 & 216.6 \\
\hline 4 & 46.2 & 47.0 & 38.5 & 38.6 & 46.7 \\
\hline 5 & 48.8 & 49.0 & 49.1 & 49.1 & 48.8 \\
\hline 6 & 27.6 & 29.2 & 26.6 & 26.5 & 27.6 \\
\hline 7 & 66.3 & 69.2 & 66.2 & 66.9 & 66.2 \\
\hline 8 & 157.8 & 159.2 & 155.9 & 156.8 & 157.4 \\
\hline 9 & 141.2 & 140.6 & 142.0 & 142.6 & 141.1 \\
\hline 10 & 38.2 & 38.2 & 38.5 & 38.8 & 38.2 \\
\hline 11 & 197.7 & 200.1 & 192.1 & 197.8 & 196.9 \\
\hline 12 & 50.1 & 52.0 & 79.8 & 49.1 & 49.9 \\
\hline 13 & 44.9 & 46.9 & 49.9 & 46.0 & 45.0 \\
\hline 14 & 59.3 & 54.1 & 60.5 & 58.8 & 59.2 \\
\hline 15 & 218.1 & 72.9 & 216.4 & 217.7 & 215.8 \\
\hline 16 & 41.2 & 36.7 & 37.3 & 38.4 & 35.6 \\
\hline 17 & 46.7 & 48.7 & 46.1 & 46.1 & 49.5 \\
\hline 18 & 17.7 & 17.4 & 13.4 & 18.4 & 19.0 \\
\hline 19 & 18.2 & 19.6 & 18.6 & 18.5 & 18.1 \\
\hline 20 & 35.5 & 36.2 & 35.5 & 143.9 & 85.9 \\
\hline 21 & 18.2 & 18.5 & 20.8 & 112.2 & 25.9 \\
\hline 22 & 34.5 & 34.8 & 33.1 & 31.3 & 34.2 \\
\hline 23 & 25.6 & 25.9 & 26.5 & 32.3 & 27.4 \\
\hline 24 & 144.1 & 145.3 & 143.2 & 177.3 & 175 \\
\hline 25 & 127.0 & 127.2 & 127.1 & & \\
\hline 26 & 171.2 & 172.0 & 171.0 & & \\
\hline 27 & 12.1 & 12.3 & 12.1 & & \\
\hline 28 & 24.7 & 19.7 & 24.1 & 24.2 & 25.0 \\
\hline 29 & 26.9 & 27.6 & 28.1 & 28.1 & 26.9 \\
\hline 30 & 20.7 & 20.9 & 15.4 & 15.4 & 20.7 \\
\hline $\mathrm{Me} \underline{\mathrm{CO}}$ & & & 170.1 & & \\
\hline$\underline{\mathrm{MeCO}}$ & & & 20.7 & & \\
\hline
\end{tabular}

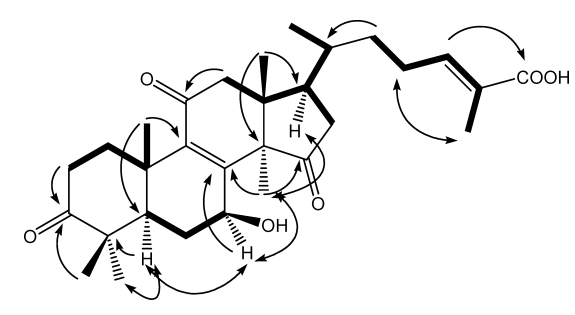

Fig. 2. Selected 2D Correlations for Ganoderic Acid GS-1 (1)

Bold lines, ${ }^{1} \mathrm{H}-{ }^{1} \mathrm{H}$ COSY; single arrows (selected), HMBC; double arrows (selected) NOESY.

(DEPT) and ${ }^{1} \mathrm{H}$-detected multiple quantum coherence (HMQC) studies, revealed signals for seven methyls, seven methylenes, five methines (including an oxymethine at $\delta_{\mathrm{C}}$ 66.3 and an $s p^{2}$ methine at $\left.\delta_{\mathrm{C}} 144.1\right)$ and eleven quaternary carbons (including three olefinic carbons at $\delta_{\mathrm{C}} 127.0,141.2$, and 157.8 , and four carbonyl carbons at $\delta_{\mathrm{C}} 171.2,197.7$, 216.8 , and 218.1). These data suggested a highly oxygenated lanostane-type triterpene similar to ganoderic acid $\beta(6) .{ }^{10)}$ However, the MS spectrum showed that the molecular weight of $\mathbf{1}$ was 2 mass units less than that of $\mathbf{6}$. Heteronuclear multiple bond correlations (HMBC) of $\mathbf{1}$ showed a carbonyl carbon $\left(\delta_{\mathrm{C}} 216.8\right)$ that had long range correlations with two methyl protons at $\delta_{\mathrm{H}} 1.11$ and $1.13\left(\mathrm{CH}_{3}-29,30\right)$ (Fig. 2). These findings indicated that a carbonyl group in $\mathbf{1}$ was located at $\mathrm{C}-3$. The $\beta$ orientation of a hydroxyl group at $\mathrm{C}-7$ was deduced from multiplicity of H-7 $\left(\delta_{\mathrm{H}} 4.86 \mathrm{dd}, J=9.0\right.$, $7.5 \mathrm{~Hz}){ }^{20)}$ which was also supported by NOE correlations between $\mathrm{H}-7$ to $\mathrm{H}_{\mathrm{ax}}-5$ and between $\mathrm{H}_{\mathrm{ax}}-5$ and $\mathrm{H}-30$ in the nuclear Overhauser effect spectroscopy (NOESY) study. The 
geometry of the double bond at C-24 was entgegen $(E)$ according to the NOE observed between $\mathrm{H}_{2}-23$ and $\mathrm{H}_{3}-27$ in the NOESY spectrum. No such correlation was evident between $\mathrm{H}-24$ and $\mathrm{H}_{3}-27$. Hence, the structure of ganoderic acid GS-1 (1) was 7 $\beta$-hydroxy-3,11,15-trioxo-lanosta8,24(E)-dien-26-oic acid.

Ganoderic acid GS-2 (2) was obtained as a white amorphous powder; $[\alpha]_{\mathrm{D}}+112.9\left(\mathrm{CHCl}_{3}\right)$. The molecular formula of 2 was estimated as $\mathrm{C}_{30} \mathrm{H}_{44} \mathrm{O}_{6}$ from the HR-EI-MS spectrum $\left(m / z 500.3149[\mathrm{M}]^{+}\right.$, Calcd for $\mathrm{C}_{30} \mathrm{H}_{44} \mathrm{O}_{6}$ 500.3138). The spectral data suggested that $\mathbf{2}$ had a similar structure to $\mathbf{1}$, but the MS spectra showed that the molecular weight of $\mathbf{2}$ was 2 mass units higher than $\mathbf{1}$, and ${ }^{1} \mathrm{H}-{ }^{1} \mathrm{H}$ correlation spectroscopy (COSY) indicated an oxymethine proton at $\delta_{\mathrm{H}} 4.79$ assignable to $\mathrm{H}-15$. The $\alpha$ orientation of a hydroxyl group at C-15 was deduced from the multiplicity of $\mathrm{H}-15\left(\delta_{\mathrm{H}} 4.79 \mathrm{dd}\right.$, $J=9.0,6.5 \mathrm{~Hz}$ ), which was also supported by an NOE correlation between $\mathrm{H}-15$ and $\mathrm{H}_{3}-18$ in the NOESY spectrum. Hence, the structure of ganoderic acid GS-2 (2) was as $7 \beta, 15 \alpha$-dihydroxy-3,11-dioxo-lanosta-8,24(E)-dien-26-oic acid.

Ganoderic acid GS-3 (3) was obtained as white amorphous powder; $[\alpha]_{\mathrm{D}}+69.1\left(\mathrm{CHCl}_{3}\right)$. The molecular formula of $\mathbf{3}$ was estimated as $\mathrm{C}_{32} \mathrm{H}_{48} \mathrm{O}_{8}$ from the HR-EI-MS spectrum ( $m / z$ 558.3184 [M] ${ }^{+}$, Calcd for $\mathrm{C}_{32} \mathrm{H}_{48} \mathrm{O}_{8}$ 558.3193). The ${ }^{1} \mathrm{H}-$ and ${ }^{13} \mathrm{C}$-NMR spectra suggested that the structure of $\mathbf{3}$ was close to 6 and that it possessed an acetoxy group. The HMBC experiment assigned an oxymethine proton at $\delta_{\mathrm{H}}$ 5.63 to $\mathrm{H}-12$. The $\beta$ orientation of the acetoxy group at $\mathrm{C}-12$ was deduced from NOE correlations between $\mathrm{H}-12$ and $\mathrm{H}_{\mathrm{ax}}{ }^{-}$ 17 or $\mathrm{H}_{3}-28$ in the NOESY experiment. Hence, the structure of ganoderic acid GS-3 (3) was $12 \beta$-acetoxy-3 $\beta, 7 \beta$-dihydroxy-11,15-dioxo-lanosta-8,24(E)-dien-26-oic acid.

We obtained 20(21)-dehydrolucidenic acid $\mathrm{N}$ (4) as a white amorphous powder; $[\alpha]_{\mathrm{D}}+108.3\left(\mathrm{CHCl}_{3}\right)$. Its molecular formula was $\mathrm{C}_{27} \mathrm{H}_{38} \mathrm{O}_{6}$ as estimated from the HR-EIMS spectrum $\left(m / z\right.$ 458.2666 $[\mathrm{M}]^{+}$, Calcd for $\mathrm{C}_{27} \mathrm{H}_{38} \mathrm{O}_{6}$ 458.2668). The ${ }^{1} \mathrm{H}-\mathrm{NMR}$ spectra suggested that 4 was structurally similar to 20(21)-dehydrolucidenic acid $\mathrm{A}(7),{ }^{16}$ which is a $\mathrm{C}_{27}$ triterpenoid. However, the MS spectra showed that the molecular weight of 4 was 2 mass units higher than that of 7 , and the ${ }^{1} \mathrm{H}-{ }^{1} \mathrm{H}$ COSY experiment assigned an oxymethine proton at $\delta_{\mathrm{H}} 3.21$ to $\mathrm{H}-3$. The $\beta$ orientation of a hydroxyl group at $\mathrm{C}-3$ was deduced from the multiplicity of H-3 $\left(\delta_{\mathrm{H}} 3.21 \mathrm{dd}, J=10.5,5.0 \mathrm{~Hz}\right){ }^{20)}$ which was supported by NOE correlations between $\mathrm{H}-3$ and $\mathrm{H}_{\mathrm{ax}}-5$ or $\mathrm{H}-30$ in the NOESY experiment. Hence, the structure of 4 was $3 \beta, 7 \beta$-dihydroxy-11,15-dioxo-25,26,27-trinorlanosta-8,20(21)-dien24-oic acid.

We obtained 20-hydroxylucidenic acid $\mathrm{A}$ (5) as a white amorphous powder; $[\alpha]_{\mathrm{D}}+184.4\left(\mathrm{CHCl}_{3}\right)$. The molecular formula of 5 was estimated as $\mathrm{C}_{27} \mathrm{H}_{38} \mathrm{O}_{7}$ from the HR-EIMS spectrum $\left(m / z\right.$ 474.2676 [M] ${ }^{+}$, Calcd for $\mathrm{C}_{27} \mathrm{H}_{38} \mathrm{O}_{7}$ 474.2618). The ${ }^{1} \mathrm{H}-\mathrm{NMR}$ spectra suggested the structure of 5 was similar to that of 20-hydroxylucidenic acid $\left.\mathrm{N}(\mathbf{8}){ }^{16}\right)$ However, the MS spectra showed that the molecular weight of $\mathbf{5}$ was 2 mass units less than that of $\mathbf{8}$. The HMBC experiment showed that a carbonyl carbon $\left(\delta_{\mathrm{C}} 216.6\right)$ had longrange correlations with two methyl protons at $\delta_{\mathrm{H}} 1.10$ and $1.13\left(\mathrm{H}_{3}-29,30\right)$. These findings indicated that a carbonyl group was located at $\mathrm{C}-3$ in $\mathbf{5}$. The absolute configuration at
C-20 remains undetermined as well as that of $\mathbf{8}$. The structure of $\mathbf{5}$ was subsequently determined as $7 \beta, 20 \xi$-dihydroxy3,11,15-trioxo-25,26,27-trinorlanost-8-en-24-oic acid.

Anti-HIV-1 Protease Activities of Compounds Isolated from Ganoderma Species Our previous publications addressing the development of naturally occurring anti-viral agents, ${ }^{21,22)}$ indicate that some triterpenes, such as ganoderic acid $\mathrm{B}$ and ganoderiol $\mathrm{B},{ }^{9)} N$ - $(3 \beta$-hydroxyolean-12-en-28oyl)-6-aminohexanoic acid, ${ }^{15)}$ hemiesters of ursolic acid, ${ }^{23)} 3$ oxotirucalla-7,24-dien-21-oic acid, ${ }^{24)} 16 \beta$-hydroxy-2,3-secolup-20(29)-en-2,3-dioic acid, ${ }^{25)}$ colossolactone $\mathrm{V}^{26)}$ and 2-Oacetyldryopteric acid $A,{ }^{27}$ potently inhibit HIV-1 PR, which is an essential enzyme for HIV proliferation. ${ }^{21,22)}$

Here we compared the abilities of 11 triterpenoids isolated from the fruiting body of $G$. sinense and 11 [ganoderic acid A (15), B (16), C1 (17), G (18), DM (19), ganoderiol A (20), ganodermadiol (21), ganodermanondiol (22), ganodermatriol (23), lucidumol A (24), and lucidumol B (25)] isolated from G. lucidum to inhibit HIV-protease. Table 3 shows the $\mathrm{IC}_{50}$ values of these compounds. Of 24(25) unsaturated ganoderic acids (such as 1, 2, 3, 6 and 19), which are the major compounds of $G$. sinense, the 3-oxo compounds were more inhibitory than the 3-hydroxy compounds. Among the lucidenic acids (such as 4, 5, 7, 8 and 9), the 3-hydroxy com-

Table 3. Anti-HIV-1 Protease Activities of Ganoderma Triterpenes

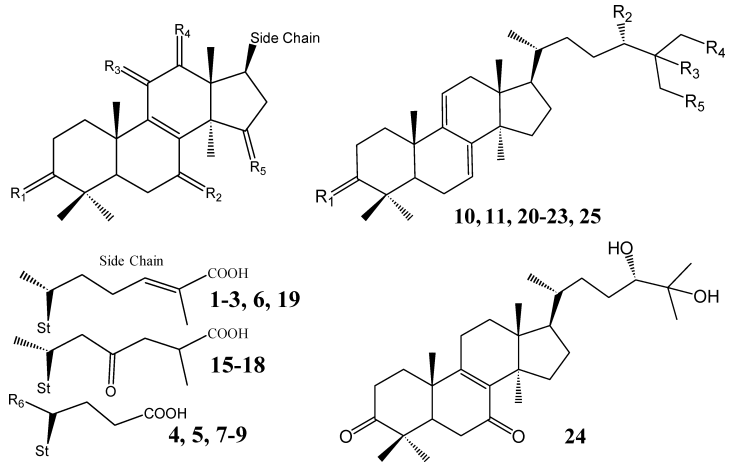

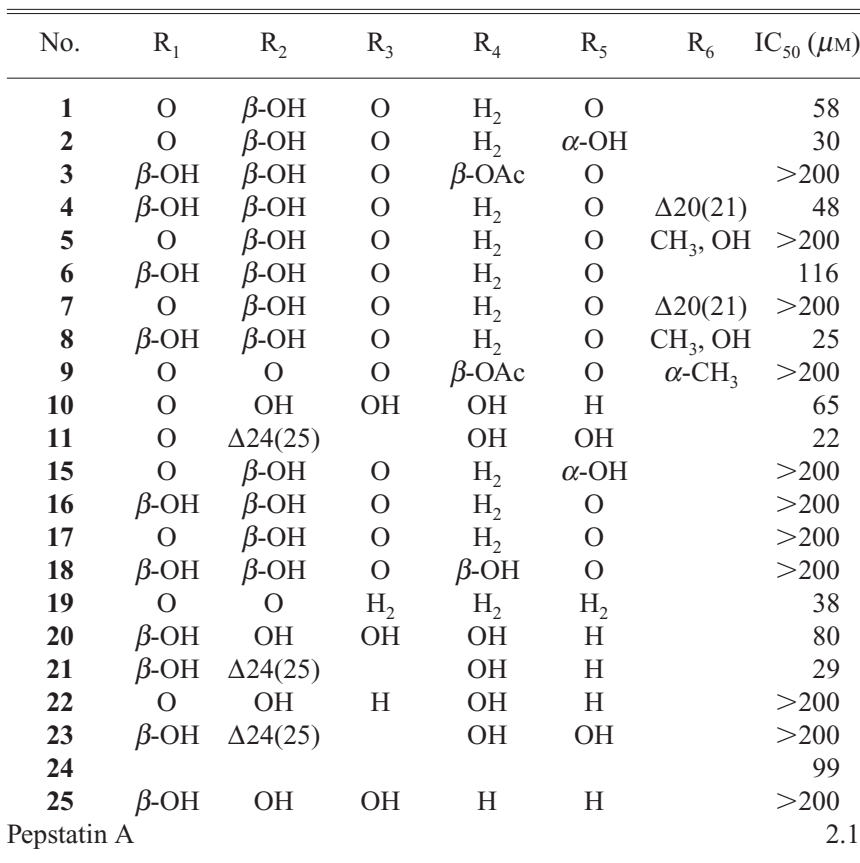


pounds were more inhibitory than the 3-oxo compounds. Among the ganoderma alcohols (such as 10, 11 and 20-25), 24(25) unsaturated compounds were more inhibitory than 24-hydroxy compounds. The 23-oxo ganoderic acids (such as 15-18), which are the major compounds of G. lucidum, had no activity against HIV-protease. Ganoderiol F (11), 20hydroxylucidenic acid N (8), ganoderic acid GS-2 (2), and 20(21)-dehydrolucidenic acid N (4) were significantly inhibitory against HIV-1 protease, with $\mathrm{IC}_{50}$ values of 22,25 , 30 and $48 \mu \mathrm{M}$, respectively.

\section{Experimental}

Optical rotation was measured using a JASCO DIP-360 automatic polarimeter and UV spectra were measured with a UV-2200 UV-VIS recording spectrophotometer (Shimadzu Co., Kyoto, Japan). We measured IR spectra with a Jasco FT/IR-230 infrared spectrometer and NMR spectra with a Varian Unity $500\left({ }^{1} \mathrm{H}, 500 \mathrm{MHz} ;{ }^{13} \mathrm{C}, 125 \mathrm{MHz}\right) \mathrm{NMR}$ spectrometer. The internal standard was tetramethyl silane (TMS) and $J$ values are reported in Hertz. The HR-EI-MS spectra were measured on a Jeol JMS-AX505HAD apparatus at an ionization voltage of $70 \mathrm{eV}$. Preparative HPLC proceeded on a Tosoh CCPM-II system (Tosoh Co., Tokyo, Japan) equipped with a UV 8020 detector and a Cholester Waters HPLC column $(20 \times 250 \mathrm{~mm})$. Column chromatography proceeded on BW-820MH silica gel (Fuji Silica Chemical Co., Aichi, Japan) or Wakogel 50C18 (38-63 $\mu \mathrm{m}$, Wako Pure Chemical Industries, Ltd.).

Plant Materials Ganoderma sinense was purchased in Hehauchi market for medicinal herbs (Chengdu, China) and identified by Dr. De-Yuan Chen (Guiyang College of Traditional Chinese Medicine, Guiyang, China). The specimen has been deposited in the Museum of Materia Medica, Institute of Natural Medicine, University of Toyama.

Enzyme Recombinant HIV-1 protease (purity $95 \%$ by sodium dodecyl sulfate-polyacrylamide gel electrophoresis) was purchased from Bachem (Feinchemikalien AG, Bubendort, Switzerland).

Extraction and Isolation Dried and chopped $G$. sinense (275 g) was extracted three times with $\mathrm{CHCl}_{3}(2 \mathrm{l})$ by refluxing for $3 \mathrm{~h}$ to afford $6.8 \mathrm{~g}$ of a solid extract. The crude extract $(6.5 \mathrm{~g})$ was eluted through a silica gel column $(4 \times 40 \mathrm{~cm})$ with hexane-acetone $(9: 1 ; \mathrm{Fr} .1,300 \mathrm{mg})$, hexane-acetone ( $7: 3 ;$ Fr. $2 ; 3.4$ g), and $\mathrm{CHCl}_{3}-\mathrm{MeOH}(1: 2 ;$ Fr. $3,1.8$ g). Fraction 2 was separated by silica gel column chromatography $(\mathrm{CC})$ into six fractions using a hexane-acetone gradient. Fraction 2-1 was separated by silica gel CC with a hexane-acetone gradient to yield ergosterol peroxide $(\mathbf{1 4}, 80 \mathrm{mg})$ and 5,6-dihydroergosterol $(13,25 \mathrm{mg})$. Fraction 2-2 was similarly separated to yield ganoderiol $\mathrm{F}(\mathbf{1 1}, 50 \mathrm{mg})$. Fraction 2-3 was separated by octadecyl silica (ODS) CC with an $\mathrm{H}_{2} \mathrm{O}-\mathrm{MeOH}$ gradient to yield 20(21)-dehydrolucidenic acid A (7, 35 mg), ganodermanontriol $(\mathbf{1 0}, 150 \mathrm{mg})$, and cerevisterol (12, $5 \mathrm{mg}$ ). Fraction 2-4 was separated by preparative HPLC (ODS column; $\mathrm{MeCN}-0.1 \%$ trifluoroacetic acid (TFA) $/ \mathrm{H}_{2} \mathrm{O}, 5 \mathrm{ml} / \mathrm{min}$ ) to yield ganoderic acid GS-1 $(\mathbf{1}, 15 \mathrm{mg})$ and ganoderic acid GS-2 $(2,10 \mathrm{mg})$. Fraction 2-5 was separated by ODS CC with an $\mathrm{H}_{2} \mathrm{O}-\mathrm{MeOH}$ gradient to yield 20(21)-dehydrolucidenic acid $\mathrm{N}(\mathbf{4}, 30 \mathrm{mg})$ and 20-hydroxylucidenic acid $\mathrm{A}(\mathbf{5}, 30 \mathrm{mg})$ Fraction 2-6 was resolved by preparative HPLC (Cholester column; $\left.\mathrm{MeOH}-0.1 \% \mathrm{TFA} / \mathrm{H}_{2} \mathrm{O}, 5 \mathrm{ml} / \mathrm{min}\right)$ to yield ganoderic acid GS-3 $(3,5 \mathrm{mg})$ and ganoderic acid $\beta(6,5 \mathrm{mg})$. Fraction 3 was separated by ODS CC with an $\mathrm{H}_{2} \mathrm{O}-\mathrm{MeOH}$ gradient to yield 20-hydroxylucidenic acid $\mathrm{N}(\mathbf{8}, 40 \mathrm{mg})$ and lucidenic acid D2 $(9,10 \mathrm{mg})$.

7 $\beta$-Hydroxy-3,11,15-trioxo-lanosta-8,24(E)-dien-26-oic Acid (1, Ganoderic Acid GS-1) Amorphous powder. $[\alpha]_{\mathrm{D}}^{23}+130.4^{\circ}\left(c=0.276, \mathrm{CHCl}_{3}\right)$. $\mathrm{UV}\left(\mathrm{CHCl}_{3}\right) \lambda_{\max }(\log \varepsilon): 252(3.9) \mathrm{nm}$. IR (KBr) $v_{\max }: 3440(\mathrm{OH}), 2880$, 1700 (carbonyl), 1660 (carboxyl), 1480, 1390, 1270, 1140, and $1060 \mathrm{~cm}^{-1}$. ${ }^{1} \mathrm{H}$ - and ${ }^{13} \mathrm{C}$-NMR $\left(\mathrm{CDCl}_{3}\right)$ spectra: see Tables 1 and 2. HR-EI-MS $\mathrm{m} / \mathrm{z}$ : $498.2982[\mathrm{M}]^{+}$(Calcd for $\mathrm{C}_{30} \mathrm{H}_{42} \mathrm{O}_{6}, 498.2981$ ).

$7 \beta, 15 \alpha$-Dihydroxy-3,11-dioxo-lanosta-8,24(E)-dien-26-oic Acid (2, Ganoderic Acid GS-2) Amorphous powder. $[\alpha]_{D}^{23}+112.9^{\circ}(c=0.403$, $\left.\mathrm{CHCl}_{3}\right)$. UV $\left(\mathrm{CHCl}_{3}\right) \lambda_{\max }(\log \varepsilon): 253(3.8) \mathrm{nm}$. IR (KBr) $v_{\max }: 3440(\mathrm{OH})$, 2880, 1700 (carbonyl), 1660 (carboxyl), 1470, 1420, 1390, 1270, 1140, and $1060 \mathrm{~cm}^{-1}$. ${ }^{1} \mathrm{H}-$ and ${ }^{13} \mathrm{C}-\mathrm{NMR}\left(\mathrm{CDCl}_{3}\right)$ spectra: see Tables 1 and 2 . HR-EIMS $m / z: 500.3139[\mathrm{M}]^{+}$(Calcd for $\mathrm{C}_{30} \mathrm{H}_{44} \mathrm{O}_{6}, 500.3138$ )

$12 \beta$-Acetoxy-3 $\beta, 7 \beta$-dihydroxy-11,15-dioxo-lanosta-8,24(E)-dien-26oic Acid (3, Ganoderic Acid GS-3) Amorphous powder. $[\alpha]_{\mathrm{D}}^{23}+69.1^{\circ}$ $\left(c=0.857, \mathrm{CHCl}_{3}\right)$. UV $\left(\mathrm{CHCl}_{3}\right) \lambda_{\max }(\log \varepsilon): 253(3.8) \mathrm{nm}$. IR $(\mathrm{KBr}) v_{\max }$ : $3440(\mathrm{OH}), 2880,1730$ (acetyl), 1700 (carbonyl), 1660 (carboxyl), 1450,
$1380,1230,1170,1040$ and $755 \mathrm{~cm}^{-1} .{ }^{1} \mathrm{H}-$ and ${ }^{13} \mathrm{C}-\mathrm{NMR}\left(\mathrm{CDCl}_{3}\right)$ spectra: see Tables 1 and 2. HR-EI-MS m/z: $558.3194[\mathrm{M}]^{+}\left(\right.$Calcd for $\mathrm{C}_{32} \mathrm{H}_{48} \mathrm{O}_{8}$, 558.3193).

$3 \beta, 7 \beta$-Dihydroxy-11,15-dioxo-25,26,27-trinorlanosta-8,20(21)-dien-24oic Acid [4, 20(21)-Dehydrolucidenic Acid N] Colorless needles. $[\alpha]_{\mathrm{D}}^{23}$ $+108.3^{\circ}\left(c=0.411, \mathrm{CHCl}_{3}\right)$. UV $\left(\mathrm{CHCl}_{3}\right) \lambda_{\max }(\log \varepsilon): 255$ (3.8) nm. IR $(\mathrm{KBr}) v_{\max }: 3450(\mathrm{OH}), 2880,1730,1700$ (carbonyl), 1660 (carboxyl), 1460, 1380, 1230, 1170, 1040 and $900 \mathrm{~cm}^{-1} \cdot{ }^{1} \mathrm{H}-$ and ${ }^{13} \mathrm{C}-\mathrm{NMR}\left(\mathrm{CDCl}_{3}\right)$ spectra: see Tables 1 and 2. HR-EI-MS m/z: $458.2666[\mathrm{M}]^{+}$(Calcd for $\left.\mathrm{C}_{27} \mathrm{H}_{38} \mathrm{O}_{6}, 458.2668\right)$.

$7 \beta, 20 \xi$-Dihydroxy-3,11,15-trioxo-25,26,27-trinorlanost-8-en-24-oic Acid (5, 20-Hydroxylucidenic Acid A) Colorless needles. $[\alpha]_{\mathrm{D}}^{23}+184.4^{\circ}$ $\left(c=0.373, \mathrm{CHCl}_{3}\right)$. UV $\left(\mathrm{CHCl}_{3}\right) \lambda_{\max }(\log \varepsilon): 254(3.8) \mathrm{nm}$. IR (KBr) $v_{\max }$ : $3480(\mathrm{OH}), 2880,1770,1700$ (carbonyl), 1660, 1460, 1420, 1390, 1210 , 1170,1130 and $1070 \mathrm{~cm}^{-1} .{ }^{1} \mathrm{H}$ - and ${ }^{13} \mathrm{C}-\mathrm{NMR}\left(\mathrm{CDCl}_{3}\right)$ spectra: see Tables 1 and 2. HR-EI-MS $m / z$ : $474.2616[\mathrm{M}]^{+}\left(\right.$Calcd for $\mathrm{C}_{27} \mathrm{H}_{38} \mathrm{O}_{7}, 474.2618$ ).

Chemicals The purity of Ganoderma triterpenes (15-25) isolated in our laboratory from the fruiting bodies of G. lucidum (provided by the Institute of Linzi Co., Ltd., Tokyo, Japan) determined by HPLC was $>99 \%$. A previously described procedure ${ }^{14)}$ was employed for the purity check, using a CCP 8020 system (Tosoh Co., Tokyo, Japan), a TSK gel ODS-80 Ts (Tosoh) column (150-4.6 mm i.d.), a mobile phase of $1 \% \mathrm{AcOH} / \mathrm{H}_{2} \mathrm{O}-\mathrm{CH}_{3} \mathrm{CN}$ (0 min, 45:55; $40 \mathrm{~min}, 40: 60$, for ganoderma alcohols) and $2 \%$ $\mathrm{AcOH} / \mathrm{H}_{2} \mathrm{O}-\mathrm{CH}_{3} \mathrm{CN}(0 \mathrm{~min}, 75: 25 ; 50 \mathrm{~min}, 70: 30 ; 70 \mathrm{~min}, 60: 40$, for ganoderma acids). The flow rate was set at $1.0 \mathrm{ml} / \mathrm{min}$ with detecting wavelengths of 243 and $250 \mathrm{~nm}$ for ganoderma alcohols and acids, respectively.

HIV-1 Protease Inhibitory Assay We assayed anti-HIV-1 protease activity following the procedure described in previous papers. ${ }^{23,26)}$ Briefly, $10 \mu \mathrm{l}$ of $50 \mathrm{~mm} \mathrm{NaOAc}$ buffer containing $1 \mu \mathrm{g}$ of substrate was mixed with $2 \mu \mathrm{l}$ of test compounds ( 7 ganoderma alcohols and 15 ganoderma acids) in DMSO and then $8 \mu \mathrm{l}$ of HIV-1 protease was added to the mixture. After incubation at $37^{\circ} \mathrm{C}$ for $30 \mathrm{~min}$, the reaction was terminated with $3 \mu \mathrm{l}$ of $10 \%$ TFA. The hydrolysate and the remaining substrate were quantified by HPLC. The anti-HIV-1 protease activity of the compound was calculated as:

$\%$ inhibition $=100 \times\left(A_{\text {control }}-A_{\text {sample }}\right) / A_{\text {control }}$

where $A$ is the relative peak area of the hydrolysate. Potency is expressed as $50 \%$ inhibitory concentration $\left(\mathrm{IC}_{50}\right)$.

\section{References}

1) Min B. S., Gao J. J., Hattori M., "Current Topics in Phytochemistry," Vol. 7, Research Trends (P) Ltd., Trivandrum, India, 2005, pp. 35-60.

2) Paterson R. M., Phytochemistry, 67, 1985-2001 (2006).

3) Cole J. R., Schweikert A. M., "Handbook of Secondary Fungal Metabolites," Vol. 2, Academic Press, San Diego, 2003, pp. 271- 430.

4) Hada S., Hattori M., Namba T., J. Med. Pharm. Soc. Wakan-Yaku, 6, 100-107 (1989).

5) Huang S. L., Hada S., Kakiuchi K., Hattori M., Kikuchi T., Namba N., Shoyakugaku Zasshi, 45, 132-136 (1991).

6) Min B. S., Gao J. J., Nakamura N., Hattori M., Chem. Pharm. Bull., 48, 1026-1033 (2000)

7) Min B., Gao J., Hattori M., Lee H., Kim Y., Planta Med., 67, 811$814(2001)$

8) Gao J. J., Hirakawa A., Min B. S., Nakamura N., Hattori M., J. Nat. Med., 60, 42-48 (2006).

9) El-Mekkawy S., Meselhy M. R., Nakamura N., Tezuka Y., Hattori M., Kakiuchi N., Shimotohno K., Kawahata T., Otake T., Phytochemistry, 49, 1651-1657 (1998).

10) Min B. S., Nakamura N., Miyashiro H., Bae K. W., Hattori M., Chem. Pharm. Bull., 46, 1607-1612 (1998).

11) Liu C., Wang H. Q., Li B. M., Chen R. Y., Zhongguo Zhongyao Zazhi, 32, 235-237 (2007).

12) Qiao Y., Zhang X. M., Qiu M. H., Molecules, 12, 2038-2046 (2007).

13) Wang X. M., Yang M., Guan S. H., Liu R. X., Xia J. M., Bi K. S., Guo D. A., J. Pharm. Biomed. Anal., 41, 838-844 (2006).

14) Gao J., Nakamura N., Min B., Hirakawa A., Zuo F., Hattori M., Chem. Pharm. Bull., 52, 688-695 (2004).

15) Ma C., Nakamura N., Hattori M., Chem. Pharm. Bull., 48, 1681$1688(2000)$.

16) Akihisa T., Tagata M., Ukiya M., Tokuda H., J. Nat. Prod., 68, 559563 (2005)

17) Kikuchi T., Kanomi S., Murai Y., Kadota S., Tsubono K., Ogita Z., Chem. Pharm. Bull., 34, 4018-4029 (1986). 
18) Fujita A., Arisawa M., Saga M., Hayashi T., Morita N., J. Nat. Prod., 49, 1122-1125 (1986).

19) Nishitoba T., Oda K., Sato H., Sakuma S., Agric. Biol. Chem., 52, $367-372$ (1988).

20) Nishitoba T., Sato H., Kasai T., Kawagishi H., Sakamura S., Agric. Biol. Chem., 49, 1793-1798 (1985).

21) Ma C. M., Nakamura N., Hattori M., "Current Topics in Medicinal Chemistry,” Vol. 3, Research Trends (P) Ltd., Trivandrum, India, 2003, pp. $77-99$.

22) Meselhy M. R., El-Mekkawy S., Ma C. M., Nakamura N., Tewtrakul S., Hattori M., J. Trad. Med., 22 (Suppl. 1), 116-128 (2005).
23) Ma C. M., Nakamura N., Miyashiro H., Hattori H., Shimotohno K., Chem. Pharm. Bull., 47, 141-145 (1999).

24) Ma C. M., Nakamura N., Hattori M., Kakuda H., Qiao J. C., Yu H. L., J. Nat. Prod., 63, 238-242 (2000).

25) El Dine R. S., El Halawany A. M., Ma C., Hattori M., J. Nat. Prod., 71, 1022-1026 (2008).

26) Wei Y., Ma C., Chen D., Hattori M., Phytochemistry, 69, 1875-1879 (2008).

27) Lee J., Miyashiro H., Nakamura N., Hattori M., Chem. Pharm. Bull., 56, $711-714$ (2008). 